\title{
Implementasi Modifikasi Kompresi Run-Length Encoding pada Steganografi
}

\author{
(Implementation of Run-Length Encoding Compression Modification on \\ Steganography) \\ Suwardiman dan Fitri Bimantoro* \\ Program Studi Teknik Informatika, Universitas Mataram \\ Jl. Majapahit 62, Mataram, Lombok NTB, INDONESIA \\ Email: imankidis@gmail.com, [gpsutawijaya,bimo]@unram.ac.id
}

*Penulis korespondensi

\begin{abstract}
RLE is one of the methods to compress data, however it has disadvantages that the compressed data may become twice larger as the original size. Therefore, in this research RLE will be modified to solve the problem. In the experiment we tested 3 file format i.e. JPG, PNG and BMP. The testing on JPG and PNG shows that conventional RLE method is not able to compress all images because it obtained negative compression ratio with an average compression ratio about $-\mathbf{9 8 , 2 \%}$, Meanwhile the compression with RLE modification shows that the all image successfully compress with an average compression ratio about $0,17 \%$. The testing on BMP shows the conventional RLE method successfully compress 5 files out of 11 tested images with average compression ratio about $-34,7 \%$, Meanwhile the compression with modified RLE successfully compress all tested images with average compression ratio about $18,8 \%$.
\end{abstract}

Key words: Steganography, First of File, End of File, compression, Run-length encoding.

\section{LATAR BELAKANG}

Steganografi [1] adalah salah satu metode yang digunakan untuk mengamankan data agar tidak mudah didapatkan serta disalahgunakan oleh orang yang tidak bertanggung jawab. Salah satu aspek steganografi adalah Imperceptibility yaitu pengukuran secara kasat mata terhadap suatu file apakah menimbulkan kecurigaan terdapat data rahasia atau tidak [2]. Teknik End of File dan First of File merupakan salah satu teknik yang digunakan dalam steganografi. Teknik ini digunakan dengan cara menambahkan data atau pesan rahasia seperti gambar maupun teks pada akhir atau awal file. Perhitungan ukuran file yang telah disisipkan data sama dengan ukuran file sebelum disisipkan data ditambah ukuran data rahasia yang telah diubah menjadi encoding file [3]. Untuk meningkatkan keamanan dari sisi imperceptibility dibutuhkan kompresi data, salah satu metode kompresi adalah RLE. Penelitian tentang Run-Length-Encoding dan steganografi menyebutkan Run-Length-Encoding menyembunyikan data hampir setengah dari ukuran file dan pesan terkompresi dapat didekompresi dengan baik [4].

Terdapat kekurangan yang dimiliki teknik kompresi Run-Length-Encoding jika diterapkan pada data pixel warna pada gambar 8 bit maupun dalam bentuk ASCII 8 bit yaitu terdapat kemungkinan hasil kompresi menjadi lebih besar dari ukuran file asli. Ini disebabkan oleh proses perhitungan panjang data juga dilakukan pada data-data yang tidak berulang. Oleh karena permasalahan tersebut pada penelitian ini akan dilakukan modifikasi terhadap teknik kompresi Run-Length-Encoding agar dapat menghilangkan kemungkinan adanya hasil kompresi yang lebih besar dari ukuran asli sehingga dapat diterapkan dengan maksimal pada steganografi First of File dan End of File.

\section{TINJAUAN PUSTAKA}

Penelitian terkait implementasi Run Length Encoding pada kompresi citra [5] menunjukkan citra yang mempunyai sebaran nilai piksel tidak merata memiliki rasio kompresi yang relatif besar sedangkan citra dengan nilai piksel yang merata memiliki rasio kompresi yang lebih kecil. Pada penelitian ini kompresi dilakukan pada citra grayscale dengan mengelompokkan pixel-pixel yang seragam, teknik kompresi masih dilakukan dengan menulis jumlah dari setiap pixel meskipun pixel tidak berulang. Perbedaannya dengan penelitian yang akan dilakukan adalah kompresi akan dilakukan pada byte data citra dengan menggunakan kompresi Run Length Encoding yang akan dimodifikasi sehingga kompresi hanya akan dilakukan pada data yang berulang lebih dari 5 kali.

Penelitian tentang teknik steganografi End of File, First of File dan kombinasinya berhasil diimplementasikan pada penyisipan citra ke citra [6]. Pada penelitian ini pesan disisipkan ke dalam pixel citra, penyisipan yang dilakukan ke dalam pixel citra membuat perubahan yang tampak secara kasat mata pada cover citra sehingga menimbulkan kecurigaan pada citra hasil penyisipan. Sehingga pada penelitian ini dilakukan penyisipan dengan metode yang 
sama tetapi penyisipan dilakukan pada byte data cover dan dilakukan kompresi terlebih dahulu pada pesan.

Penelitian tentang kompresi Run-Length-Encoding pada citra digital yang telah dilakukan menunjukkan kompresi Run-Length-Encoding tanpa modifikasi yaitu dengan menuliskan jumlah setiap data walaupun data tersebut tidak berulang akan menyebabkan hasil kompresi menjadi lebih besar dari ukuran file asli. Terlihat pada hasil pengujian terdapat rasio yang $-0,08 \%$ yang artinya hasil kompresi lebih besar 0,08 \% dari ukuran asli. Melihat hasil tersebut pada penelitian ini akan diterapkan Run-LengthEncoding yang akan dimodifikasi sehingga hanya data-data yang berulang lebih dari 5 data yang akan dikompresi [7].

\section{STEGANOGRAFI}

Metode ini merupakan metode pengembangan LSB. Dalam metode ini pesan disisipkan di akhir berkas. Teknik EOF atau End of File merupakan salah satu teknik yang digunakan dalam steganografi. Teknik ini menggunakan cara dengan menyisipkan data pada akhir file. Teknik ini dapat digunakan untuk menyisipkan data yang ukurannya sesuai dengan kebutuhan [8]. Ukuran file yang telah disisipkan data sama dengan ukuran file sebelum disisipkan data ditambah dengan ukuran data yang disisipkan ke dalam file tersebut.

Dengan metode EOF, secara umum media steganografi (file yang akan disisipi data) memiliki struktur seperti Gambar 1:

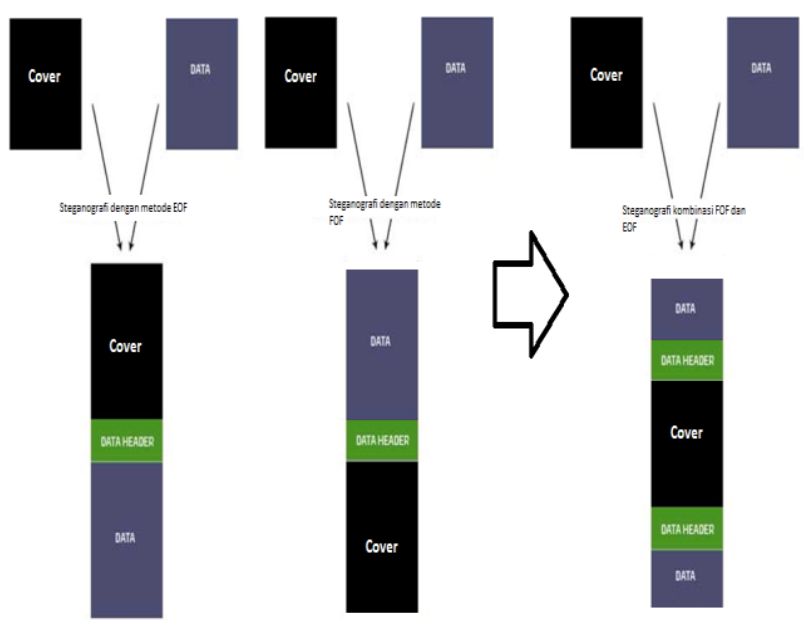

Gambar 1. Struktur File Steganografi dengan Metode EoF, FOF dan Kombinasi EOF dan FOF [3]

Pada penelitian ini diterapkan steganografi First of File, End of File serta kombinasi First of File dan End of File. Berbeda dengan penelitian sebelumnya [6] yang menyisipkan pesan pada pixel cover, pada penelitian ini akan dilakukan penyisipan pada byte data dengan aturan yaitu pada First of File data akan disisipkan seluruhnya di awal dari cover. Pada metode End of File data akan disisipkan seluruhnya di akhir file. Pada metode kombinasi First of File dan End of File data akan disisipkan sebanyak 1000 data genap di awal dari file serta menyisipkan 1000 data ganjil dan sisa data lainnya di akhir file.

\section{KOMPRESI RUN LENGTH ENCODING}

Algoritma RLE menggunakan pendekatan ruang. Algoritma ini cocok digunakan untuk memampatkan citra yang memiliki kelompok-kelompok piksel berderajat keabu-abuan yang sama. Citra yang mempunyai sebaran nilai piksel tidak merata memiliki rasio kompresi yang relatif besar sedangkan citra dengan nilai piksel yang merata memiliki rasio kompresi yang lebih kecil [5]. Metode ini dilakukan dengan menyatakan seluruh baris citra menjadi sebuah baris run, lalu menghitung run length untuk setiap derajat keabu-abuan yang berurutan [9].

Contoh, diketahui sebuah citra memiliki byte data sebagai berikut dalam vektor:

(1121463144444444627223411)

Hasil kompresi:

$=(1,2)(2,1)(1,1)(4,1)(6,2)(3,1)(1,1)(4,8)(6,1)(2,1)(7,2)$

$(2,2)(3,1)(4,1)(1,2)$

$=\left(\begin{array}{l}1221114162311148612172314112\end{array}\right)$

Sebelum dikompresi $=25 * 1$ byte $=25$ byte

Sesudah dikompresi $=28 * 1$ byte $=28$ byte $100 \%-28 / 25 \times 100 \%=-12 \%$

Terlihat pada contoh, hasil kompresi menjadi lebih besar dari ukuran file asli sebanyak $12 \%$.

Terdapat tipe RLE lainnya yaitu I2DRLE [10] yang diterapkan pada citra. Pada RLE ini pencarian data pixel yang sama dilakukan dengan blok-blok persegi, garis atau segitiga. Pada RLE ini tidak terdapat penanda dinamis, hanya terdapat informasi blok-blok yang menyusun citra. RLE ini hanya pernah dilakukan pengujian pada citra grayscale yang terdiri dari piksel $1 / 0$ belum ada penelitian terkait RLE tipe ini untuk citra RGB.

\section{KOMPRESI RUN LENGTH ENCODING MODIFIKASI}

Kompresi RLE tanpa modifikasi pada penelitianpenelitian sebelumnya [7][11] menunjukkan hasil kompresi menjadi lebih besar dari ukuran sebelum dikompresi maka pada penelitian ini dilakukan modifikasi pada algoritma kompresi sehingga tidak terdapat data hasil kompresi yang menjadi lebih besar dari data sebelum dikompresi yaitu dengan mengelompokkan data byte yang sama dari citra dan penulisan jumlah data hanya dilakukan pada byte yang berulang lebih dari 5 kali. Jika menerapkan teknik modifikasi ini maka diperlukan byte penanda yang digunakan untuk mengetahui bahwa byte data tersebut merupakan byte yang terkompresi. Penentuan penanda dilakukan dengan mencari byte yang memiliki frekuensi kemunculan terkecil dari byte pesan, byte ini yang akan dijadikan sebagai penanda.

Contoh, diketahui sebuah citra memiliki byte data sebagai berikut dalam vektor:

(1121463144444444627223411) Hasil kompresi menjadi:

(1 121463408627223411 )

Sebelum dikompresi $=25 * 1$ byte $=25$ byte

Sesudah dikompresi $=20 * 1$ byte $=20$ byte

$100 \%-20 / 25 \times 100 \%=20 \%$ 
Terlihat hasil kompresi menjadi lebih baik dengan rasio kompresi $20 \%$ dengan tidak mengkompresi data yang memiliki panjang data berulang $<5$. Byte data $\left(\begin{array}{lll}4 & 0 & 8\end{array}\right)$ adalah merupakan hasil kompresi, dengan byte 0 sebagai penanda, penanda didapatkan dari mencari frekuensi kemunculan setiap byte. Seperti yang terlihat pada Tabel I byte 0 memiliki frekuensi 0 .

\section{TABEL I. FREKUENSI BYTE}

\begin{tabular}{|c|c|}
\hline Byte & Frekuensi \\
\hline 0 & 0 \\
\hline 1 & 6 \\
\hline 2 & 4 \\
\hline 3 & 2 \\
\hline 4 & 10 \\
\hline 5 & 0 \\
\hline 6 & 2 \\
\hline 7 & 1 \\
\hline
\end{tabular}

Pemilihan panjang data berulang minimal 5 dilakukan untuk menghindari hasil kompresi yang lebih besar dari ukuran asli, pada modifikasi ini akan terdapat 3 kasus pencarian frekuensi yaitu:

a. Terdapat byte data yang berfrekuensi 0 sehingga membutuhkan 1 penanda saja.

b. Penanda hasil kompresi dengan 2 tanda, jika tidak terdapat byte berfrekuensi 0 maka akan dilakukan pencarian penanda baru dengan 2 tanda tetapi tetap memperhatikan byte data yang memiliki frekuensi terkecil.

c. Penanda hasil kompresi dengan 3 tanda, jika tidak terdapat byte kombinasi yang sesuai dengan 2 tanda maka akan dilakukan pencarian penanda baru dengan 3 tanda dan tetap memperhatikan byte data yang memiliki frekuensi terkecil.

Dengan melihat kasus ketiga yaitu dengan 3 penanda, maka ada kemungkinan jika mengkompresi data yang memiliki data berulang $<5$ akan terjadi penambahan jumlah byte yang tidak perlu.

\section{IMPLEMENTASI}

Aplikasi ini secara garis besar memiliki dua proses utama yaitu penyisipan (embedding) pesan dan ekstraksi (extraction) pesan yang tersembunyi. Hubungan antara kedua proses tersebut dapat dilihat pada Gambar 2.

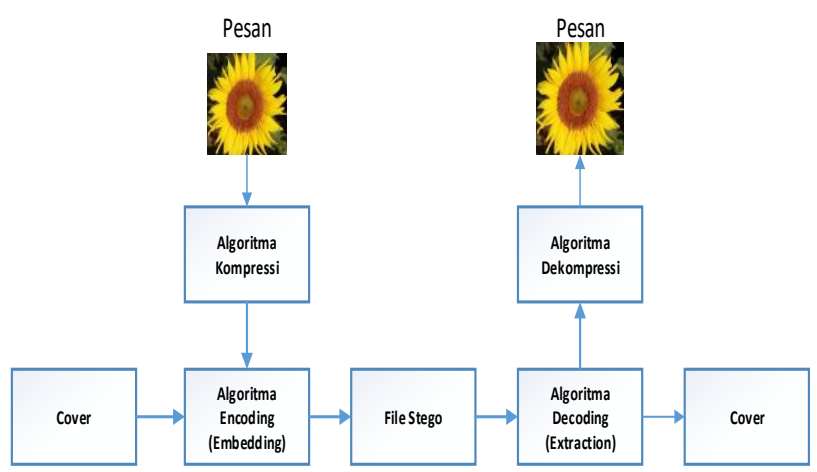

Gambar 2. Proses penyisipan dan ekstraksi pesan
Proses penyisipan pesan dimulai dengan memilih file gambar yang akan menjadi pesan rahasia dan dilakukan kompresi gambar untuk mengurangi ukuran dari pesan. Selanjutnya memilih file yang menjadi cover sebagai tempat penyisipan pesan. Langkah selanjutnya yaitu penyisipan pesan rahasia pada file cover (Embedding). Berikutnya yaitu ekstraksi pesan rahasia yang dimulai dengan memilih file stego. Kemudian mendapatkan kembali informasi pesan rahasia dengan melakukan ekstraksi sesuai dengna algoritma. Data hasil ekstraksi merupakan data yang masih terkompresi dan harus dilakukan dekompressi lagi untuk mendapatkan pesan asli.

\section{A.1. Proses Penyisipan Pesan}

Berikut merupakan algoritma dalam tahap untuk menyisipkan pesan rahasia pada citra, dapat dilihat pada Gambar 3.

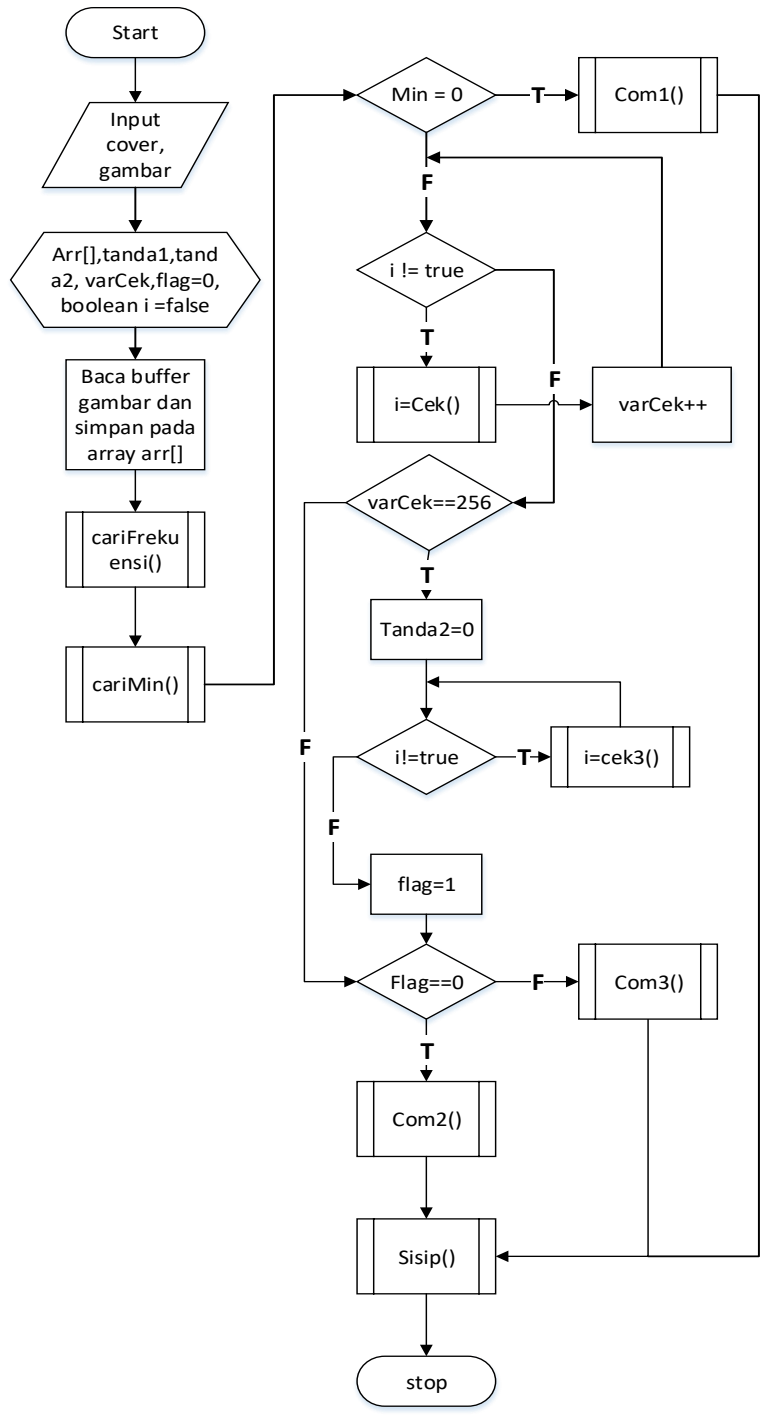

Gambar 3. Diagram alir penyisipan pesan

Gambar 3. merupakan diagaram alir untuk penyisipan pesan, berikut langkah-langkah penyisipan pesan citra ke dalam cover: 
1. Langkah awal yang dilakukan yaitu input file gambar yang menjadi pesan rahasia dan file cover.

2. Baca byte file gambar, lalu hitung frekuensi kemunculan setiap byte dari $0-255$.

Misalkan diketahui sebuah file gambar bertipe PNG memiliki byte sebagai berikut:

[225692688888888899775597623155 56710012345227462111000000000000 $\left.\begin{array}{lllllllllll}0 & 0 & 0 & 0 & 0 & 0 & 0 & 0 & 0 & 8 & 9\end{array}\right]$

3. Dapatkan frekuensi terkecil yang akan digunakan sebagai penanda hasil kompressi. Berdasarkan bytebyte di atas didapatkan sebuah tabel frekuensi pada Tabel II.

TABEL II. CONTOH FREKUENSI BYTE

\begin{tabular}{|c|c|c|c|}
\hline Byte & Frekuensi & Byte & Frekuensi \\
\hline 0 & 21 & 45 & 1 \\
\hline 1 & 3 & 46 & 1 \\
\hline 2 & 4 & 55 & 2 \\
\hline 5 & 1 & 56 & 1 \\
\hline 6 & 3 & 99 & 1 \\
\hline 7 & 5 & 100 & 1 \\
\hline 8 & 10 & 123 & 1 \\
\hline 9 & 3 & 231 & 1 \\
\hline 22 & 1 & Total & 60 \\
\hline
\end{tabular}

4. Kemudian mencari kombinasi yang tidak ada pada byte data gambar antara byte yang memiliki frekuensi terkecil dengan byte $0-255$.

Contoh pada poin 2 terdapat byte yang berfrekuensi 0 yang artinya tidak ada pada file pesan oleh karenanya byte berfrekuensi 0 dapat dijadikan penanda hasil kompresi. Pada contoh pada poin 2 penanda yang digunakan adalah 3.Setelah itu lakukan kompressi RLE dengan mencari byte-byte data yang memiliki keseragaman lebih dari 5 akan dimampatkan seperti contoh dibawah ini:

[ 225695688888888899775597623155 56710012345227465111000000000000 $\left.\begin{array}{llllllllllllllll}0 & 0 & 0 & 0 & 0 & 0 & 0 & 0 & 0 & 8 & 9\end{array}\right]$

Hasil kompresi:

[ 2255695683999775597623155567100 12345227465111032189 ]

5. Setelah data hasil kompresi didapatkan maka dilakukan penulisan pada file cover byte-byte hasil compresi, pada kasus ini penyisipan dilakukan menggunakan kombinasi First of File dan End of File dengan aturan semua index genap akan disisipkan pada First of File cover dan index ganjil akan disisipkan pada End of File cover. Misalkan byte-byte cover sebagai berikut:

[5623789245713378348900235178 95680976323123578113427809782 3]

Hasil penyisipan:

[ 30259639979655712322461138112110 103333562378924571337834890023 51789568097632312357811342780
9782333326589755723156100457510 $21901]$

Angka berwarna hijau diawal byte adalah penanda hasil compresi, angka berwarna biru adalah penanda atau flag batas dari pesan dan cover dan angka hijau sebelum [ [ $\left.\begin{array}{lll}3 & 3 & 3\end{array}\right]$ adalah type file pesan yang disisipkan dalam ASCII [112 110 103] yang artinya PNG. Angka [1] pada akhir file adalah penanda pesan disisipkan dengan menggunakan kombinasi First of File dan End of File. Angka [0] pada length-2 adalah penanda pesan dikompresi dengan 1 penanda.

6. Selesai file gambar berhasil disisipkan pada file cover.

\section{A.2. Proses Ekstraksi Pesan}

Berikut merupakan proses dari proses ekstraksi pesan yang telah disisipkan pada file atau citra stego, diagram alir dapat dilihat pada Gambar 4.

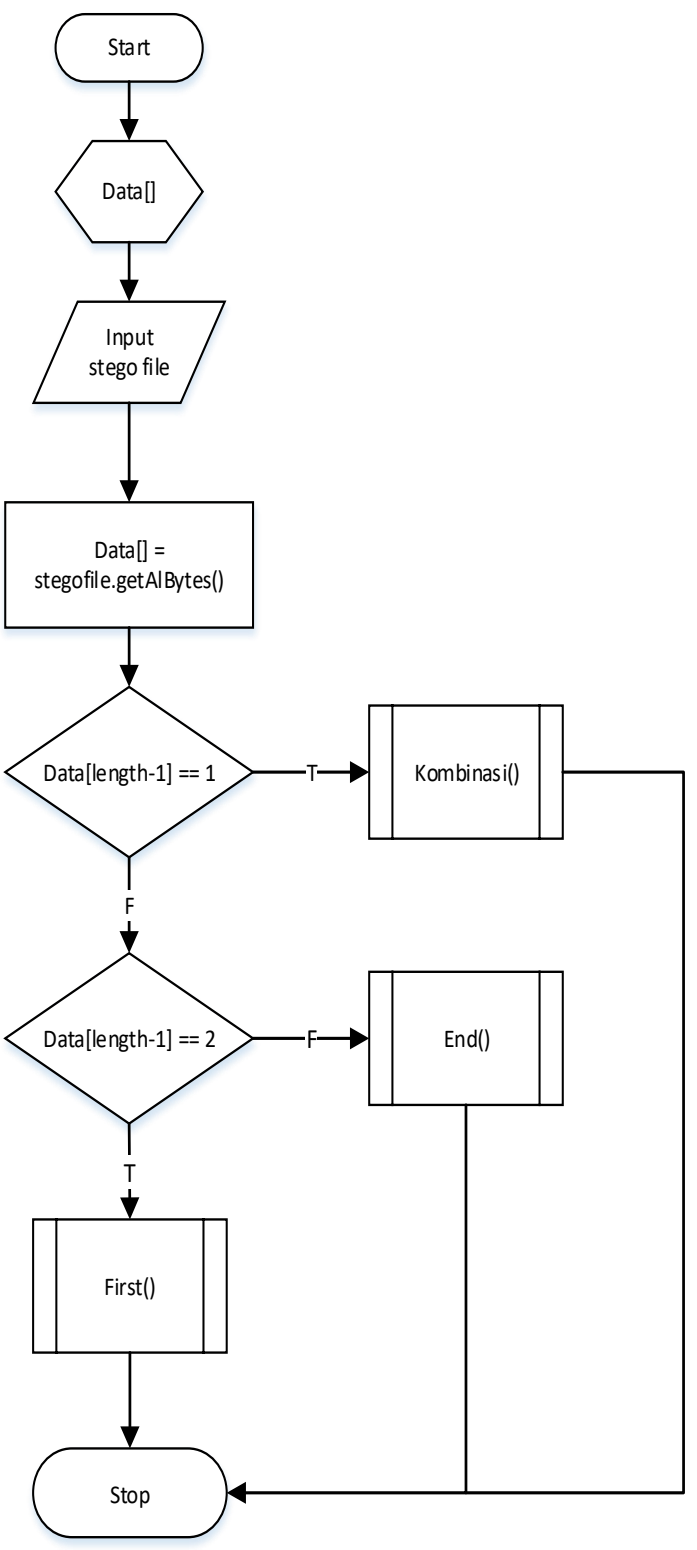

Gambar 4. Diagram alir ekstraksi pesan 


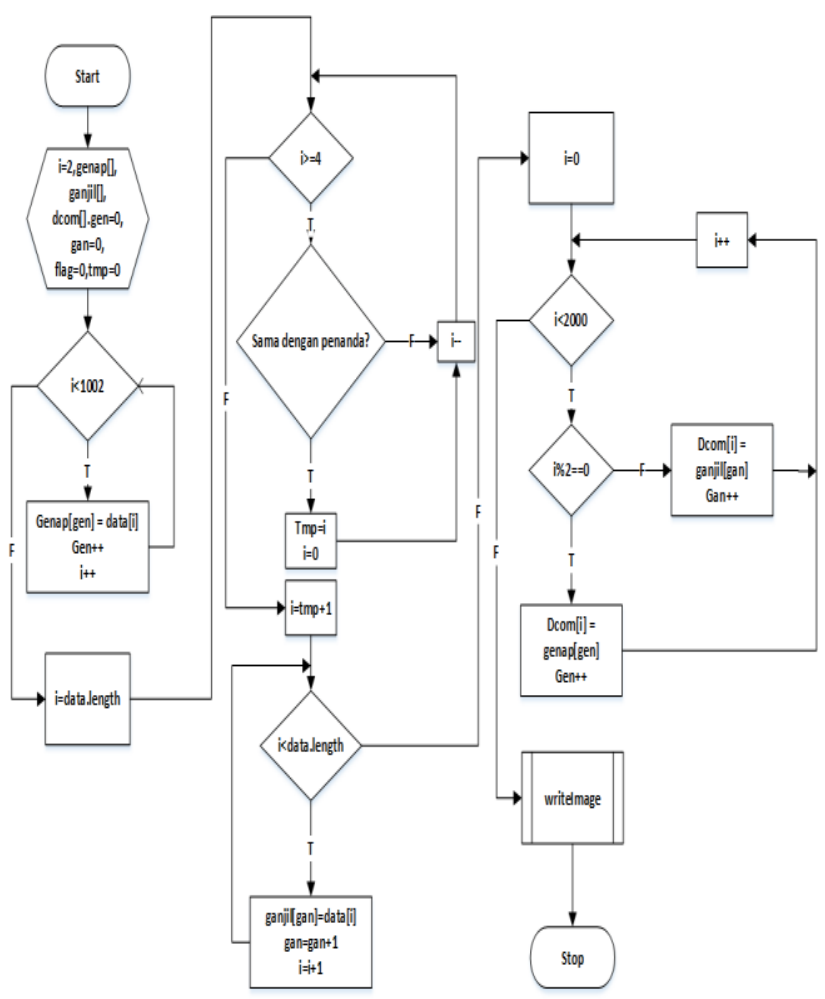

Gambar 5. Diagram alir mendapatkan pesan terkompesi

1. Langkah awal yang dilakukan yaitu input file stego yang sudah disisipkan pesan

2. Baca byte file stego.

Misalkan diketahui sebuah file stego memiliki byte sebagai berikut:

[ 30259639979655712322461138112110 103333562378924571337834890023 51789568097632312357811342780 9782333326589755723156100457510 $21901]$

3. Byte terakhir data adalah penanda pesan disisipkan dengan metode First of File, End of File atau kombinasi keduanya, pada kasus byte bernilai [1] artinya pesan disisipkan dengan metode kombinasi First of File dan End of File.

4. Byte ke-0 dan ke-1 adalah merupakan penanda dan bukan merupakan bagian dari byte pesan. Byte-byte awal dimasukan kedalam array byte genap dimulai dari data ke-2 hingga 3 byte terakhir sebelum ditemukan data dengan kombinasi [ $\left[\begin{array}{lll}3 & 3 & 3\end{array}\right]$ secara berurutan.

[ 30259639979655712322461138112110 103333562378924571337834890023 51789568097632312357811342780 9782333326589755723156100457510 $219001]$

Maka didapatkan byte genap adalah: (259639979655712322461138)

5. Melanjutkan mencari data [ $\left[\begin{array}{lll}3 & 3 & 3\end{array}\right]$ untuk mendapatkan byte ganjil dari pesan, pencarian dilakukan dimulai dari belakang, jika ditemukan maka byte setelahnya hingga byte akhir merupakan byte ganjil.
[ 30259639979655712322461138112110 103333562378924571337834890023 51789568097632312357811342780 9782333326589755723156100457510 $21901]$

Maka didapatkan byte ganjil adalah:

(26589755723156100457510219)

6. Byte genap dan byte ganjil ditulis disimpan pada satu array secara bergantian dimulai dari byte genap hingga akhir. Pada tahap ini sudah didapatkan byte file pesan gambar yang masih terkompresi.

[ 225695683999775597623155567100 $12345227465111032189]$

7. Pada byte length- 2 adalah bernilai 0 artinya pesan terkompressi dengan menggunakan 1 penanda. Maka dilakukan pencarian byte terkompress dengan memperhitungkan 1 penanda yaitu data ke-0 [3] menjadi:

[ 225695683999775597623155567100 $12345227465111032189]$

8. Dekompresi dilakukan dengan menulis kembali bytebyte sebelum penanda sebanyak angka yang ada tepat setelah angka 3, misalkan pada contoh [8 3 9] maka hasil dekompresi adalah [8 88888888 8] $\rightarrow$ 8 ditulis sebanyak 9 kali. Langkah 7 berlaku pada byte-byte selanjutnya hingga akhir data.

[225695688888888899775597623155 56710012345227465111000000000000 000000000000089 ]

9. Byte-byte hasil dekompresi ditulis pada sebuah file dan disimpan sesuai dengan type file yang sudah didapatkan dari file stego. Pada contoh type file adalah PNG dengan nilai ASCII 112110103.

10. Selesai file pesan berhasil didapatkan

\section{HASIL DAN PEMBAHASAN}

Pengujian untuk membandingkan dua metode kompresi pada percobaan ini dilakukan dengan mengukur rasio kompresi yang dihasilkan pada berbagai jenis gambar pesan dengan beragam ukuran. Serta pengujian kualitas metode steganografi pada percobaan ini dilakukan dengan beberapa cara yaitu, menghitung nilai MSE dan PSNR file stego gambar dan file pesan setelah recovery.

Bahan yang digunakan untuk melakukan pengujian tersebut menggunakan 33 gambar pesan terdiri dari 11 bertipe JPG, 11 bertipe PNG dan 11 bertipa BMP. Terdapat 11 jenis file cover yang digunakan bertipe DOCX, PPTX, XLSX, PDF, JPG dan PNG. Adapun daftar pesan gambar yang digunakan dalam percobaan ini dapat dilihat pada Tabel III. 
TABEL III. Daftar Pesan Gambar Yang DIgunakan Dalam PENGUJIAN
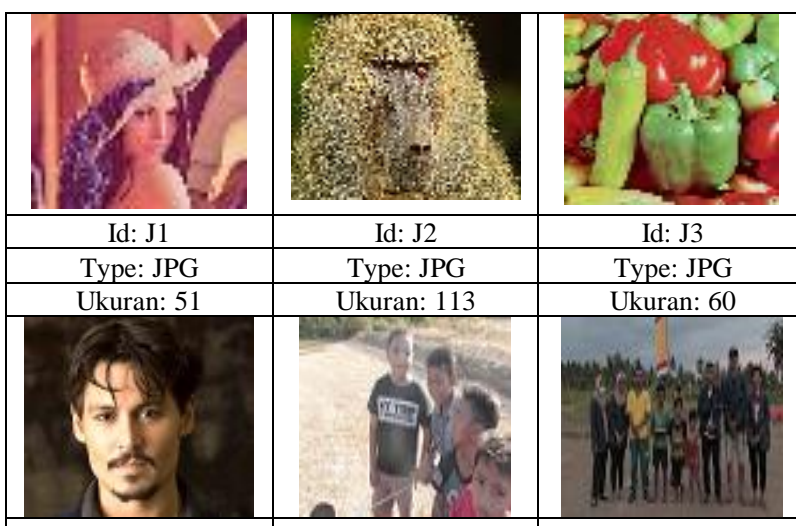

Id: J4

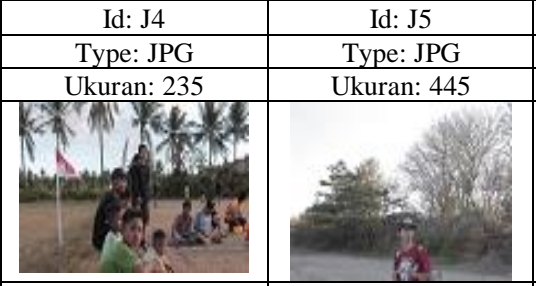

Id: J7 Id: J8
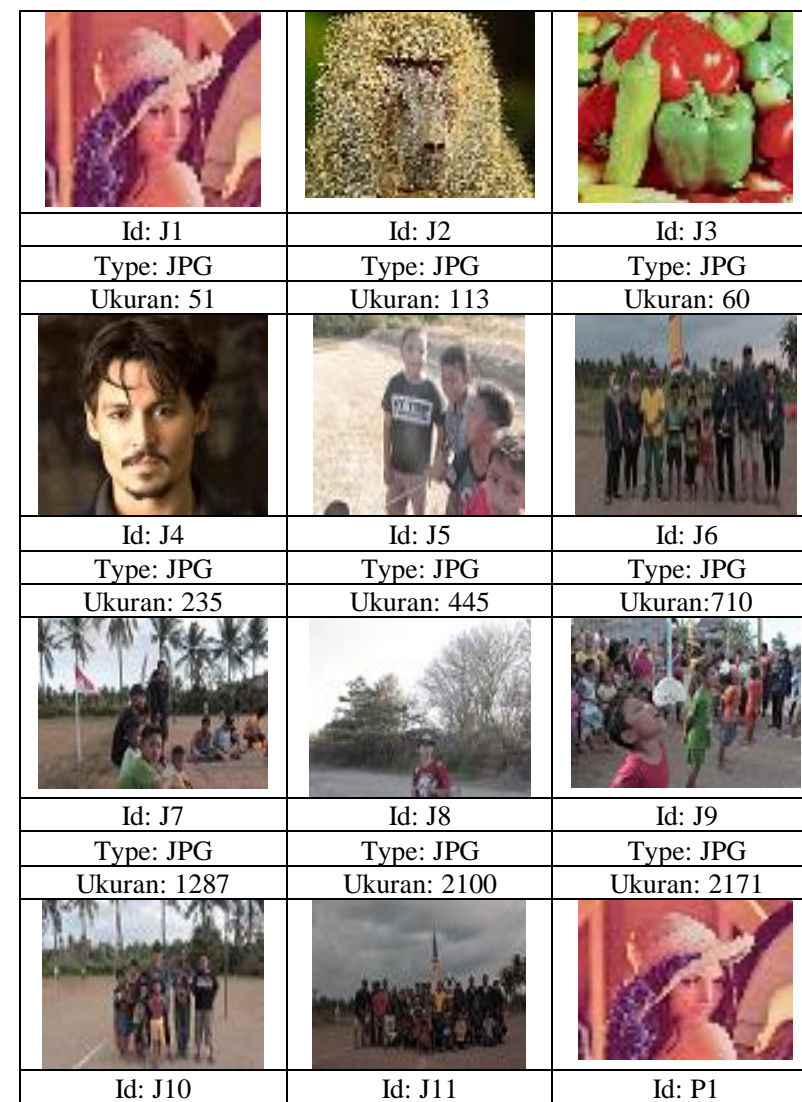

ype: JPG Ukuran: 2100

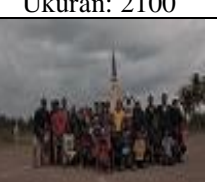

Id: J11 Type: JPG
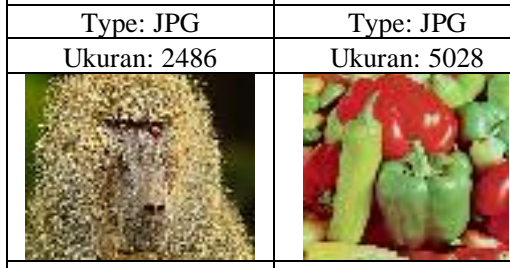

Id: P2

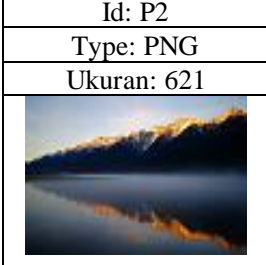

Id: P3
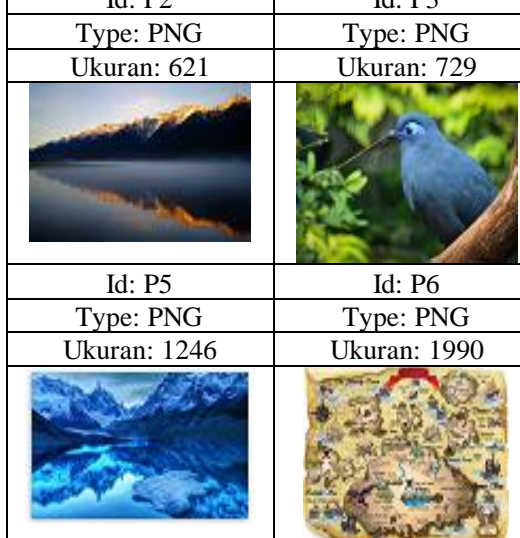
Id: P6
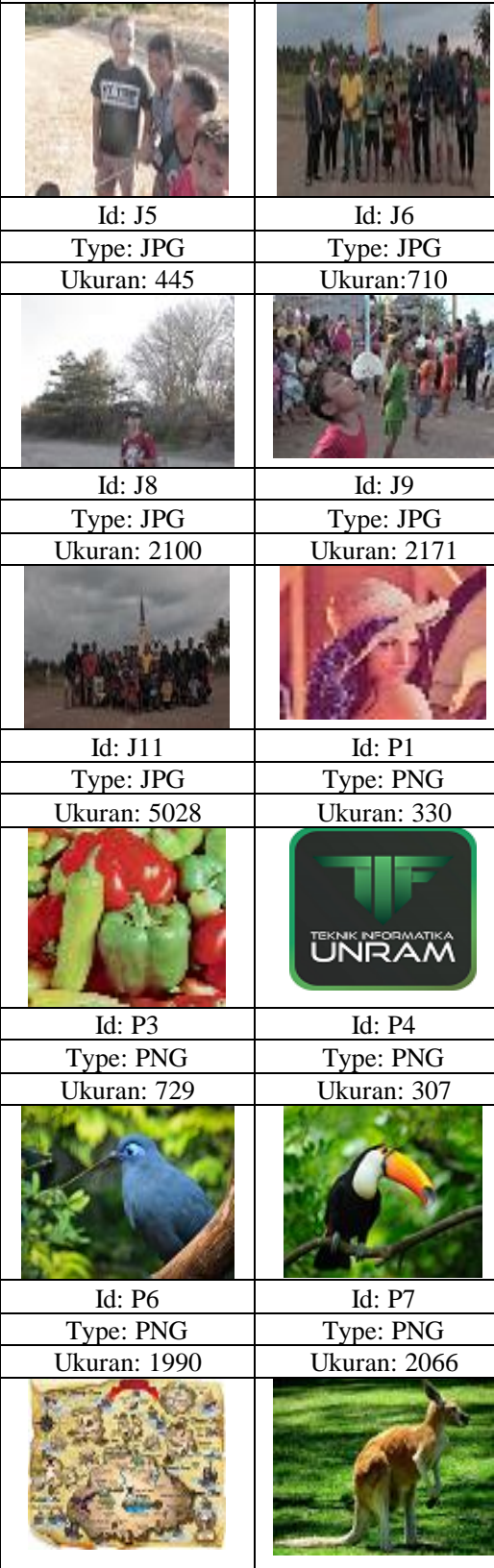

Id: J6

Id: J6
Type: JPG
Ukuran:710

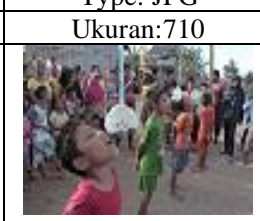

Id: J9

\begin{tabular}{|c|}
\hline Id: J9 \\
\hline Type: JPG \\
\hline Ukuran: 2171
\end{tabular}

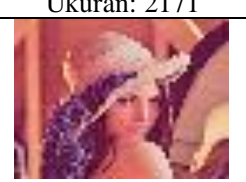

Id: P1

Id: P1

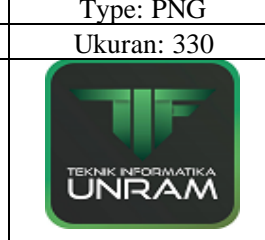

Id: P4

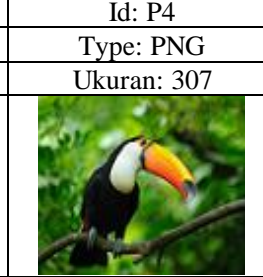

Id: P7

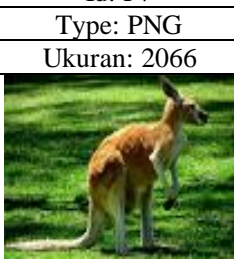

Id: P10

\begin{tabular}{|c|c|c|}
\hline Id: P8 & Id: P9 & Id: P10 \\
\hline Type: PNG & Type: PNG & Type: PNG \\
\hline Ukuran: 2368 & Ukuran: 3059 & Ukuran: 3506 \\
\hline & & \\
& & \\
& & \\
& & \\
Id: P11 & Id: B1 & \\
\hline
\end{tabular}

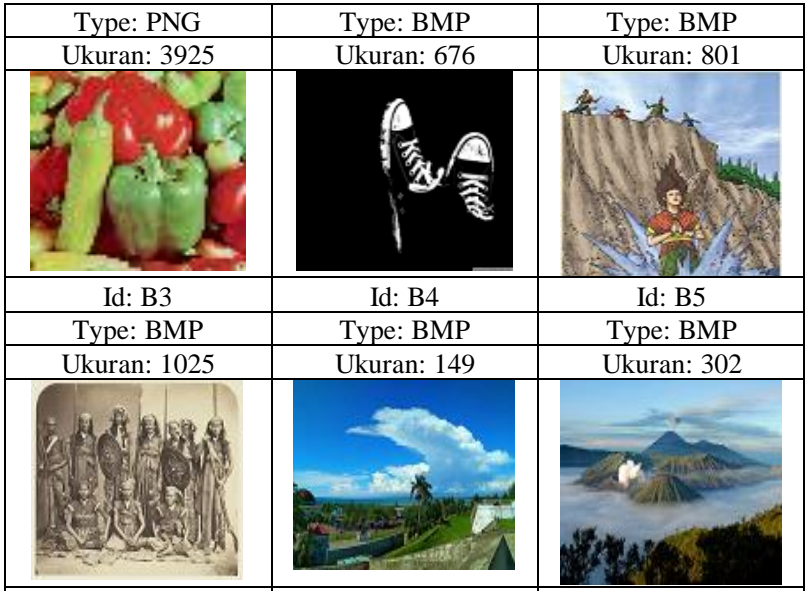

\begin{tabular}{|c|c|c|}
\hline Id: B6 & Id: B7 & Id: B8 \\
\hline Type: BMP & Type: BMP & Type: BMP \\
\hline
\end{tabular}

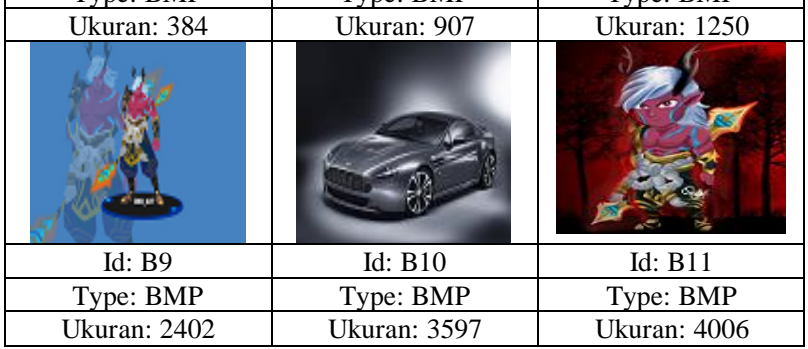

Selain pesan gambar bahan lainnya yang dibutuhkan pada proses pengujian ini adalah file cover. Informasi mengenai file cover yang digunakan pada percobaan ini dapat dilihat pada Tabel IV.

TABEL IV. Daftar File Cover YANG DigunaKan DALAM PROSES PENGUJIAN

\begin{tabular}{|c|c|c|c|}
\hline No. & $\begin{array}{c}\text { FILE } \\
\text { CovER }\end{array}$ & $\begin{array}{c}\text { JENIS } \\
\text { FILE }\end{array}$ & $\begin{array}{c}\text { UKURAN FILE } \\
\text { (KB) }\end{array}$ \\
\hline 1 & PPT1 & PPTX & 242 \\
\hline 2 & PPT2 & PPTX & 3444 \\
\hline 3 & JPG1 & JPG & 445 \\
\hline 4 & JPG2 & JPG & 654 \\
\hline 5 & DOC1 & DOCX & 576 \\
\hline 6 & DOC2 & DOCX & 622 \\
\hline 7 & XL1 & XLSX & 55 \\
\hline 8 & XL2 & XLSX & 31 \\
\hline 9 & PDF1 & PDF & 1221 \\
\hline 10 & PDF2 & PDF & 1321 \\
\hline 11 & PNG1 & PNG & 1636 \\
\hline
\end{tabular}

\section{A. Hasil Pengujian}

\section{A.1. Rasio Kompresi}

Pengujian Rasio kompresi bertujuan untuk mengetahui dan membandingkan metode kompresi RLE tanpa modifikasi dan RLE dengan modifikasi. Besarnya rasio kompresi merupakan salah satu indikator baik atau tidaknya sebuah algoritma kompresi yang digunakan. 
Pengujian dilakukan dengan menyisipkan 33 pesan gambar pada 11 cover Sebelum disisipkan gambar akan terlebih dahulu dikompresi dengan dua metode yaitu RLE modifikasi dan RLE tanpa modifikasi. Hasil pengujian dapat dilihat pada Tabel V.

TABEL V. RASIO KOMPRESI

\begin{tabular}{|c|c|c|c|}
\hline No. & Pesan & Rasio RLE (\%) & $\begin{array}{c}\text { Rasio RLE } \\
\text { Modifikasi }(\%)\end{array}$ \\
\hline 1 & B4 & 75,81 & 83,7300 \\
\hline 2 & B9 & 43,85 & 63,0000 \\
\hline 3 & B11 & $-16,85$ & 19,6300 \\
\hline 4 & B10 & $-3,57$ & 16,4000 \\
\hline 5 & B7 & $-30,29$ & 13,9900 \\
\hline 6 & B8 & $-44,71$ & 3,5200 \\
\hline 7 & B6 & $-77,06$ & 3,2500 \\
\hline 8 & $\mathrm{~J} 7$ & $-95,00$ & 1,3900 \\
\hline 9 & B5 & $-80,80$ & 1,2100 \\
\hline 10 & B1 & $-75,11$ & 1,0900 \\
\hline 11 & $\mathrm{~J} 6$ & $-96,87$ & 0,8860 \\
\hline 12 & B2 & $-87,41$ & 0,8600 \\
\hline 13 & B3 & $-85,41$ & 0,4600 \\
\hline 14 & $\mathrm{~J} 5$ & $-97,99$ & 0,4330 \\
\hline 15 & J8 & $-98,38$ & 0,2850 \\
\hline 16 & J9 & $-98,38$ & 0,2770 \\
\hline 17 & $\mathrm{~J} 10$ & $-98,43$ & 0,2440 \\
\hline 18 & $\mathrm{~J} 11$ & $-98,55$ & 0,1610 \\
\hline 19 & $\mathrm{~J} 1$ & $-98,59$ & 0,1300 \\
\hline 20 & $\mathrm{~J} 2$ & $-98,92$ & 0,0500 \\
\hline 21 & $\mathrm{~J} 3$ & $-98,62$ & 0,0400 \\
\hline 22 & $\mathrm{~J} 4$ & $-99,07$ & 0,0270 \\
\hline 23 & P5 & $-98,41$ & 0,0053 \\
\hline 24 & P8 & $-98,70$ & 0,0009 \\
\hline 25 & P7 & $-98,59$ & 0,0008 \\
\hline 26 & P10 & $-98,95$ & 0,0006 \\
\hline 27 & P3 & 99,29 & 0,0006 \\
\hline 28 & P11 & $-97,67$ & 0,0003 \\
\hline 29 & P6 & $-98,80$ & 0,0002 \\
\hline 30 & $\mathrm{P} 9$ & $-98,48$ & 0,0001 \\
\hline 31 & P4 & $-98,46$ & 0,0001 \\
\hline 32 & P1 & $-98,01$ & 0,0000 \\
\hline 33 & $\mathrm{P} 2$ & $-97,01$ & 0,0000 \\
\hline
\end{tabular}

\section{Rasio Kompresi JPG dan PNG}

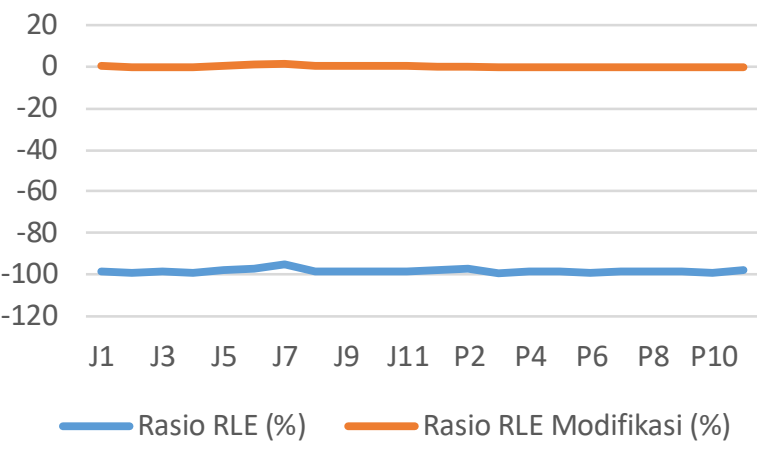

Gambar 6. Grafik rasio kompresi JPG dan PNG

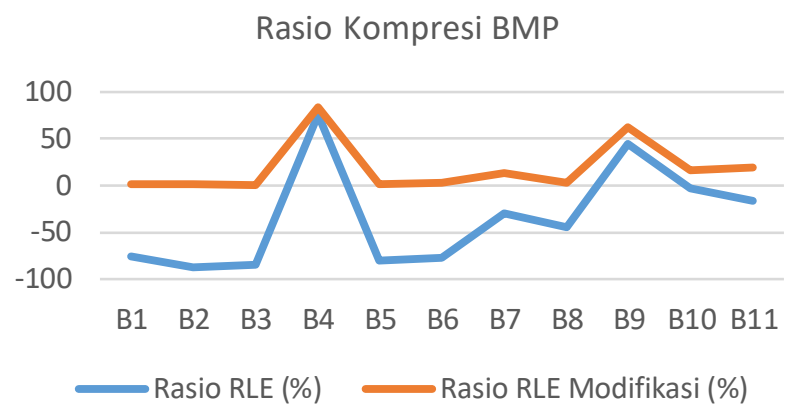

Gambar 7. Grafik rasio kompresi BMP

Berdasarkan data pada Tabel V rasio kompresi dengan menggunakan metode RLE modifikasi menunjukkan hasil yang lebih baik dari metode RLE tanpa modifikasi, ditunjukkan dengan sebanyak 22 data JPG dan PNG menghasilkan rasio negatif setelah dilakukan kompresi dengan RLE tanpa modifikasi yang artinya data hasil kompresi menjadi lebih besar dari ukuran data sebelum terkompresi. Sebaliknya dengan data yang sama dilakukan kompresi menggunakan RLE modifikasi menunjukkan 22 data memiliki rasio $>0$ artinya data hasil kompresi lebih kecil dari data sebelum dilakukan kompresi.

Pengujian algoritma kompresi pada gambar berformat BMP menunjukkan hasil yang sangat baik dengan melihat grafik pada Gambar 6 dan Gambar 7. Ini juga ditunjukkan dengan nilai rasio kompresi dengan menggunakan RLE modifikasi meningkat sangat tinggi pada gambar yang memiliki warna yang seragam begitu juga dengan kompresi dengan RLE tanpa modifikasi juga memiliki rasio yang tinggi, tetapi pada beberapa gambar yang memiliki kombinasi warna yang beragam seperti data uji dengan id B1, B3, B5, B6, dan B7, rasio kompresi RLE modifikasi terlihat lebih baik jika dibandingkan dengan RLE tanpa modifikasi pada gambar yang sama. Ini ditunjukkan dengan dengan semua data yang diuji menghasilkan rasio > 0, sebaliknya pada RLE tanpa modifikasi terdapat beberapa data yang menghasilkan rasio negatif yang artinya data hasil kompresi menjadi lebih besar dari ukuran data sebelum terkompresi. 
Kompresi RLE dengan modifikasi menjadi lebih baik dari RLE tanpa modifikasi disebabkan oleh kompresi dengan modifikasi tidak ikut memperhitungkan data yang tidak berulang atau sama. Sedangkan RLE tanpa modifikasi ikut memperhitungkan data yang tidak berulang untuk dikompresi sehingga sangat memungkinkan jika terdapat sebuah data yang memiliki tingkat keragaman byte/pixel data sangat tinggi hasil kompresi yang didapatkan dengan RLE tanpa modifikasi menjadi lebih besar dari data sebelum dilakukan kompres.

\section{A.2. Fidelity}

Pengujian nilai PSNR (Peak Signal to Noise Ratio) dilakukan untuk mengetahui kualitas file stego. Proses pengujian ini akan menghasilkan nilai MSE (Mean Square Error) dan nilai PSNR dari sebuah file stego. Semakin kecil nilai MSE yang dihasilkan maka semakin baik kualitas file stego. Pengujian nilai PSNR pada percobaan ini dilakukan terhadap file stego gambar dan file pesan hasil proses ekstraksi. Tabel VI merupakan hasil pengujian nilai MSE dan PSNR [12] dalam percobaan ini.

Tabel VI merupakan tabel hasil perhitungan nilai MSE dan PSNR pada file stego gambar dan file pesan hasil dari proses ekstraksi yang sudah melalui proses dekompresi. Pengujian pada file cover ini bertujuan untuk memeriksa kesamaan file cover sebelum dan setelah digunakan dalam metode steganografi ini. Selain itu pengujian ini juga digunakan untuk mengukur tingkat keberhasilan algoritma ekstraksi dan dekompresi yang digunakan. Jika hasil pengujian MSE semakin mendekati nol maka akan semakin baik. Terdapat beberapa data yang berlabel NA atau Not Available artinya pengujian MSE dan PSNR tidak dapat dilakukan karena bukan merupakan sebuah file gambar.

Berdasarkan hasil pengujian file stego gambar pada Tabel VI dapat dilihat bahwa seluruh nilai MSE yang dihasilkan adalah 0, MSE dengan nilai 0 menyebabkan hasil perhitungan PSNR Infinity artinya data PSNR dari file tersebut tak hingga karena MSE seusai dengan persaman 2-3 menjadi pembagi pada proses perhitungan PSNR. MSE dengan nilai 0 menunjukkan bahwa file cover gambar sebelum dan sesudah disisipkan adalah identik. Pada file stego PDF, XLSX, DOCX, PPTX, JPG, dan PNG dengan menggunakan metode steganografi First of File memiliki kelemahan hanya dapat dibuka dengan beberapa reader. Kelemahan metode First of File ini disebabkan oleh penempatan data di awal dari suatu file dapat mengganggu isi file dan menyebabkan CRC (Cyclic Redundancy Check) file rusak. Cyclic Redundancy Check (CRC) adalah salah satu fungsi hash yang dikembangkan untuk mendeteksi kerusakan data dalam proses transmisi ataupun penyimpanan. CRC menghasilkan suatu checksum yaitu suatu nilai dihasilkan dari fungsi hash-nya, dimana nilai inilah yang nantinya digunakan untuk mendeteksi error pada transmisi ataupun penyimpanan data. Ketika CRC dari suatu file rusak maka CRC tidak dapat lagi menggambarkan isi dari suatu file.
TABEL VI. HASil Perhitungan MSE dan PSNR

\begin{tabular}{|c|c|c|c|c|c|c|}
\hline $\begin{array}{c}\text { Pes } \\
\text { an }\end{array}$ & Metode & $\begin{array}{c}\text { Cov } \\
\text { er }\end{array}$ & $\begin{array}{c}\text { MSE } \\
\text { Pesan } \\
\text { Recove } \\
\text { ry }\end{array}$ & $\begin{array}{c}\text { PSNR } \\
\text { Pesan } \\
\text { Recovery }\end{array}$ & $\begin{array}{c}\text { MSE } \\
\text { Cove } \\
\mathbf{r}\end{array}$ & $\begin{array}{l}\text { PSNR } \\
\text { cover }\end{array}$ \\
\hline J5 & \multirow{29}{*}{$\begin{array}{c}\text { End of } \\
\text { Fille }\end{array}$} & JPG & 0 & Infinity & 0 & Infinity \\
\hline J6 & & PNG & 0 & Infinity & 0 & Infinity \\
\hline $\mathrm{J} 11$ & & JPG & 0 & Infinity & 0 & Infinity \\
\hline P5 & & JPG & 0 & Infinity & 0 & Infinity \\
\hline P6 & & PNG & 0 & Infinity & 0 & Infinity \\
\hline P11 & & JPG & 0 & Infinity & 0 & Infinity \\
\hline B5 & & JPG & 0 & Infinity & 0 & Infinity \\
\hline B6 & & JPG & 0 & Infinity & 0 & Infinity \\
\hline B7 & & PNG & 0 & Infinity & 0 & Infinity \\
\hline $\mathrm{J} 1$ & & docx & 0 & Infinity & NA & NA \\
\hline $\mathrm{J} 2$ & & pptx & 0 & Infinity & NA & NA \\
\hline $\mathrm{J} 3$ & & xlxs & 0 & Infinity & NA & NA \\
\hline $\mathrm{J} 7$ & & docx & 0 & Infinity & NA & NA \\
\hline $\mathrm{J} 8$ & & pptx & 0 & Infinity & NA & NA \\
\hline J9 & & xlxs & 0 & Infinity & NA & NA \\
\hline P1 & & docx & 0 & Infinity & NA & NA \\
\hline $\mathrm{P} 2$ & & pptx & 0 & Infinity & NA & NA \\
\hline P3 & & xlxs & 0 & Infinity & NA & NA \\
\hline $\mathrm{P} 7$ & & docx & 0 & Infinity & NA & NA \\
\hline P8 & & pptx & 0 & Infinity & NA & NA \\
\hline P9 & & xlxs & 0 & Infinity & NA & NA \\
\hline $\mathrm{B} 1$ & & PDF & 0 & Infinity & NA & NA \\
\hline B2 & & PDF & 0 & Infinity & NA & NA \\
\hline B3 & & $\begin{array}{c}\text { Doc } \\
x\end{array}$ & 0 & Infinity & NA & NA \\
\hline B4 & & $\begin{array}{c}\text { Doc } \\
x\end{array}$ & 0 & Infinity & NA & NA \\
\hline B8 & & Pptx & 0 & Infinity & NA & NA \\
\hline B9 & & pptx & 0 & Infinity & NA & NA \\
\hline $\begin{array}{c}\text { B1 } \\
0\end{array}$ & & xlsx & 0 & Infinity & NA & NA \\
\hline $\begin{array}{c}\text { B1 } \\
1 \\
\end{array}$ & & xlsx & 0 & Infinity & NA & NA \\
\hline $\mathrm{J} 4$ & Kombin & PDF & 0 & Infinity & NA & NA \\
\hline $\mathrm{P} 4$ & & PDF & 0 & Infinity & NA & NA \\
\hline $\mathrm{J} 10$ & First of & PDF & 0 & Infinity & NA & NA \\
\hline P10 & $F$ & PDF & 0 & Infinity & NA & NA \\
\hline
\end{tabular}

NA : Not Available

Berdasarkan Tabel VI nilai MSE pada pesan setelah diekstraksi dibandingkan dengan pesan sebelum disisipkan dan dikompresi seluruhnya menghasilkan nilai 0 . Hal tersebut menandakan bahwa seluruh file pesan hasil 
proses ekstraksi dapat kembali ke bentuk sebelumnya seperti file pesan sebelum proses penyisipan.

\section{A.3. Imperceptibility}

Kriteria ini merupakan kriteria yang diukur dengan cara hanya melihat secara kasat mata, untuk melihat kemampuan steganografi dalam penelitian ini digunakan kuesioner yang dibagikan kepada beberapa orang yang melihat perbedaan cover sebelum dan sesudah dilakukan penyisipan pesan serta pesan sebelum disisipkan dan setelah dilakukan ekstraksi. Untuk melihat dan menguji imperceptibility maka digunakan kuesioner yang dibagikan kepada 30 responden. Pertanyaan-pertanyaan dan hasil dari kuesioner dapat dilihat pada Tabel VII.

TABEL VII. PERTANyAAN DAN HASIL KUESIONER

\begin{tabular}{|c|l|l|l|l|l|l|}
\hline No & Pertanyaan & $\mathbf{1}$ & $\mathbf{2}$ & $\mathbf{3}$ & $\mathbf{4}$ & $\mathbf{5}$ \\
\hline 1 & $\begin{array}{l}\text { Terdapat } \\
\text { perbedaan antara } \\
\text { file cover dengan } \\
\text { file stego? }\end{array}$ & 33,3 & 56,6 & 9,9 & 0 & 0 \\
\hline $\begin{array}{l}\text { Terdapat } \\
\text { perubahan } \\
\text { makna kata atau } \\
\text { informasi dan } \\
\text { dimensi pada file } \\
\text { stego 46,6 } \\
\text { dibandingkan } \\
\text { dengan cover? }\end{array}$ & $\begin{array}{l}\text { Terdapat } \\
\text { perubahan } \\
\text { terhadap pesan } \\
\text { gambar sebelum } \\
\text { dan sesudah } \\
\text { diekstrak? }\end{array}$ & 49,9 & 36,6 & $6,6 \%$ & 0 & 0 \\
\hline
\end{tabular}

\section{Keterangan :}

Skor dalam persen $(\%)$

$1=$ Sangat Tidak Setuju $3=$ Cukup $5=$ Sangat Setuju $2=$ Tidak Setuju

$$
4 \text { = Setuju }
$$

Hasil kuesioner pertanyaan satu dan dua menunjukkan pesan berhasil disembunyikan dengan baik pada file cover sehingga ketika dilihat dengan kasat mata orang tidak dapat mengetahui jika file sudah disisipkan pesan gambar. Hasil kuesioner pertanyaan 3 menunjukkan pesan berhasil diekstraksi dan didekompresi dengan baik sehingga dapat dibaca dan memiliki tingkat kesamaan yang tinggi antara pesan sebelum dan sesudah disisipkan.

\section{A.4. Robustness}

Pengujian Robustness atau ketahanan dilakukan untuk mengetahui kemampuan dari file stego ketika file stego mengalami perubahan apakah data pesan rahasia mengalami gangguan atau bahkan tidak dapat diekstraksi. Tabel VIII merupakan tabel hasil pengujian pada file-file cover yang diuji pada penelitian, setelah disisipkan pesan kemudian file-file tersebut dilakukan pengubahan terhadap isi dari file dan dilakukan ekstraksi terhadap file tersebut.
TABEL VIII. Hasil PEnguJian RobustNesS

\begin{tabular}{|l|l|l|}
\hline No. & File Cover & Berhasil diekstraksi \\
\hline 1. & PDF & Tidak \\
\hline 2. & JPG & Tidak \\
\hline 3. & PNG & Tidak \\
\hline 4. & DOCX & Tidak \\
\hline 5. & PPTX & Tidak \\
\hline 6. & XLSX & Tidak \\
\hline
\end{tabular}

Berdasarkan Tabel VIII dapat disimpulkan file hasil penyisipan atau stego objek dari metode First of File, End of File atau kombinasinya akan mengalami kerusakan ketika isi dalam file mengalami perubahan sekecil apapun, ini dapat disebabkan oleh perubahan byte data pada file stego sehingga informasi terkait pesan mengalami perubahan yang dapat menyebabkan pesan tidak dapat diekstraksi kembali.

\section{KESIMPULAN DAN SARAN}

\section{A. Kesimpulan}

Dari penelitian yang telah dilakukan kesimpulan yang telah didapatkan yaitu sebagai berikut:

1. Kompresi RLE dengan modifikasi berhasil memperbaiki kekurangan RLE konvensional yaitu tidak terdapat hasil kompresi yang menjadi lebih besar dari ukuran sebelum dikompresi. Ini ditunjukkan dengan rata-rata rasio kompresi dengan RLE pada JPG, PNG dan BMP sebesar $-71,03 \%$ sedangkan RLE dengan modifikasi sebesar 6,4\%.

2. Kompresi dengan menggunakan RLE Modifikasi atau RLE tanpa modifikasi lebih baik jika diterapkan pada gambar BMP dibandingkan dengan gambar JPG dan PNG, ini ditunjukkan oleh data dimana rata-rata hasil kompresi pada file berformat BMP lebih besar yaitu $18,8 \%$ jika dibandingkan JPG dengan PNG yang memiliki rata-rata $0,17 \%$ menggunakan RLE modifikasi dan memiliki rasio $-34,7 \%$ jika dibandingkan JPG dengan PNG yang memiliki ratarata $-98,2 \%$ menggunakan RLE tanpa modifikasi.

3. Metode First of File tidak dapat diterapkan pada file bertipe JPG, PNG, DOCX, XLSX dan PPTX, ini disebabkan karena penempatan data di awal file akan merusak file asli karena mengganggu isi file asli dan merusak CRC (Cyclic Redundancy Check) file.

4. Metode steganografi dengan First of File, End of File dan kombinasinya memiliki kelemahan terkait ketahanannya terhadap perubahan data, pengujian yang dilakukan pada berbagai format stego setelah disisipkan pesan menunjukkan setelah dilakukan pengubahan pada file stego, pesan tidak dapat diekstraksi dari file.

\section{B. Saran}

Saran untuk penelitian selanjutnya penggunaan metode steganografi First of File, End of File dan kombinasi dapat dimodifikasi agar dapat diterapkan pada berbagai file cover. Pada algoritma kompressi RLE dapat dikembangkan lagi konsep penanda pada hasil kompressi 
sehingga tidak perlu melakukan komputasi yang tinggi dalam melakukan pencarian penanda.

\section{DAFTAR PUSTAKA}

[1] Muslih dan E.H. Rachmawanto, Penerapan Steganografi Pada Citra / Image Dengan Metode End of File (Eof) Sebagai Aplikasi Pengamanan Data Multimedia, Semarang, 2014.

[2] M. Edisuryana., R. Isnanto, dan M. Soemantri, "Aplikasi Steganografi Pada Citra Berformat Bitmap Dengan Menggunakan Metode EOF", TRANSIENT, Vol.2, No. 3, 2013.

[3] Martono dan Irawan, "Penggunaan Steganografi dengan Metode End of File (EOF) pada Digital Watermarking", TRANSIENT, Vol.2, No. 1

[4] S. Khan, T. Khan, dan N. Ahmad, "Run Length Encoding Based Loseless Compressedimage Steganography", Sindh University Research Journal (Science Series), 2015.

[5] A. Jalaluddin dan Y. Melita, "Implementasi Metode Run Length Encoding (RLE) untuk Kompresi Citra", Jurnal Teknika Volume 3 No 2, 2012.

[6] Arfiyah, Perbandingan Teknik Steganografi Dengan Metode First-Of-File, End-Of-File Dan Kombinasi First-
Of File Dan End-Of-File Pada File Bitmap, Sumatera Utara, 2013.

[7] W. Kusdianti, A. Septiarini, Kompresi Pada Citra Digital Menggunakan Algoritma Run Length Encoding, Scan Vol. IX, ISSN 1978-0087, 2014.

[8] Sukrisno dan E. Utami,"Implementasi Steganografi Teknik EOF, Ridjandel, Shift Cipher, dan Fungsi Hash MD5", Seminar Nasional Teknologi 2007 (SNT 2007) ISSN: 1978 - 9777: D1-D16, 2007.

[9] C.T. Utari, "Implementasi Algoritma Run Length Encoding Untuk Perancanganaplikasi Kompresi Dan Dekompresi File Citra",Jurnal TIMES, Vol. V No 2 : 24-31,2016.

[10] P. Wu, S. Zhou, F. Fang, dan S. Zhou, "An Improved TwoDimensional Run-Length Encoding Scheme and Its Application" vol. 9, no. 4, pp. 339-346, 2016.

[11] K. Fahmi, "Kompresi Citra Menggunakan Metode Run Length Encoding (Rle) Dan Algoritma Aritmetic Coding Jurnal INFOTEK, Vol 1, No 2, ISSN 2502-6968, 2016.

[12] G.M. Male, Wirawan, dan E. Setijadi, "Analisa Kualitas Cttra pada Steganografi untuk Aplikasi e-Government", Prosiding Seminar Nasional Manajemen teknologi XV, Program studi MMT-ITS, Surabaya, 2012. 